\title{
Sustainable Agriculture Reviews
}

Volume 13

Series Editor

Eric Lichtfouse

For further volumes:

http://www.springer.com/series/8380 


\title{
Books
}

Scientific Writing for Impact Factor Journals

Sustainable Agriculture

Sustainable Agriculture Volume 2

Environmental Chemistry. Green Chemistry and Pollutants in Ecosystems

Rédiger pour être publié ! Conseils pratiques pour les scientifiques

\section{Journals and series}

Agronomy for Sustainable Development

Sustainable Agriculture Reviews

Environmnental Chemistry Letters

Environmental Chemistry for a Sustainable World

\author{
Articles \\ Documents: see hal.archives-ouvertes.fr \\ Lists: see ResearchID and Citations Google Scholar \\ Presentations: see Slideshare
}

\section{Call for review articles}

Authors wishing to publish a review article in Sustainable Agriculture Reviews or Environmental Chemistry for a Sustainable World should contact the Editor.

E-mail: Eric.Lichtfouse@dijon.inra.fr 
Eric Lichtfouse

Editor

\section{Sustainable Agriculture Reviews}

Volume 13

望 Springer 


\author{
Editor \\ Dr. Eric Lichtfouse \\ UMR1347 Agroécologie \\ 17 , rue Sully \\ 21000 Dijon, France
}

ISSN 2210-4410

ISBN 978-3-319-00914-8

ISSN 2210-4429 (electronic)

ISBN 978-3-319-00915-5 (eBook)

DOI 10.1007/978-3-319-00915-5

Springer Heidelberg New York Dordrecht London

Library of Congress Control Number: 2013932220

(C) Springer International Publishing Switzerland 2014

This work is subject to copyright. All rights are reserved by the Publisher, whether the whole or part of the material is concerned, specifically the rights of translation, reprinting, reuse of illustrations, recitation, broadcasting, reproduction on microfilms or in any other physical way, and transmission or information storage and retrieval, electronic adaptation, computer software, or by similar or dissimilar methodology now known or hereafter developed. Exempted from this legal reservation are brief excerpts in connection with reviews or scholarly analysis or material supplied specifically for the purpose of being entered and executed on a computer system, for exclusive use by the purchaser of the work. Duplication of this publication or parts thereof is permitted only under the provisions of the Copyright Law of the Publisher's location, in its current version, and permission for use must always be obtained from Springer. Permissions for use may be obtained through RightsLink at the Copyright Clearance Center. Violations are liable to prosecution under the respective Copyright Law.

The use of general descriptive names, registered names, trademarks, service marks, etc. in this publication does not imply, even in the absence of a specific statement, that such names are exempt from the relevant protective laws and regulations and therefore free for general use.

While the advice and information in this book are believed to be true and accurate at the date of publication, neither the authors nor the editors nor the publisher can accept any legal responsibility for any errors or omissions that may be made. The publisher makes no warranty, express or implied, with respect to the material contained herein.

Printed on acid-free paper

Springer is part of Springer Science+Business Media (www.springer.com) 


\section{Contents}

Leaf-Cutting Ants, Biology and Control ...................................................

Isabelle Boulogne, Harry Ozier-Lafontaine, and Gladys Loranger-Merciris

Impact of Pesticide Productivity on Food Security

József Popp, Károly Petô, and János Nagy

Farmland Birds and Arable Farming, a Meta-Analysis

J.C. Wilcox, A. Barbottin, D. Durant, M. Tichit, and D. Makowski

Phytoremediation, Transgenic Plants and Microbes

Kambaska Kumar Behera

Management of Pathogens of Stored Cereal Grains

Neeta Sharma and Avantina S. Bhandari

Allelopathy for Pest Control.

Kambaska Kumar Behera and Renu Bist

Rice Bed Planting and Foliar Fertilization

M.H.M. Bhuyan, Most R. Ferdousi, and Md. Toufiq Iqbal

Integrated Nutrient Management and Postharvest of Crops

Hassan R. El-Ramady

Intercropping Taro and Bambara Groundnut

Tafadzwanashe Mabhaudhi and A.T. Modi

Land Productivity and Food Security in Zhangjiagang, China

Chengming Sun, Xiaoyu Gan, Zhengguo Sun, Tao Liu,

Ting Tian, Lijian Wang, and Jianlong Li

Index 